\title{
ЕВРООБЛИГАЦИИ КАК ИНВЕСТИЦИОННЫЙ ИНСТРУМЕНТ ДЛЯ ЧАСТНЫХ ИНВЕСТОРОВ
}

\author{
Е. И. Игнатенко, И. А. Алексеева \\ Байкальский государственный университет, г. Иркутск, Российская Федерация
}

\author{
Информация о статье \\ Дата поступления \\ 12 июля 2017 г. \\ Дата принятия к печати \\ 28 февраля 2018 г. \\ Дата онлайн-размещения \\ 30 марта 2018 г.

\section{Ключевые слова} \\ Еврооблигации; \\ еврооблигационные продукты; \\ инвестиции; рынок ценных \\ бумаг; частные инвесторы
}

\begin{abstract}
Аннотация
В настоящий момент частные инвесторы, как правило, ставят перед собой цель разместить денежные средства в надежные инструменты с доходностью выше уровня инорляции. На основе анализа российского сегмента вторичного рынка еврооблигаций, сравнения доходности еврооблигаций и вкладов в коммерческих банках показано, что инструментом, сочетающим в себе высокую надежность, умеренный уровень ликвидности и доходность выше, чем процентные ставки по банковским вкладам, являются еврооблигации. В ходе работы уточнена сущность еврооблигаций, определены ключевые характеристики и особенности еврооблигаций как инвестиционного инструмента. Представлен круг участников и инфраструктура рынка данного финансового инструмента. Изучены еврооблигационные продукты, предлагаемые инвесторам российскими инвестиционными компаниями и банками, определены параметры нового финансового продукта на основе еврооблигаций, предназначенного для частных инвесторов.
\end{abstract}

\section{EUROBONDS AS AN INVESTMENT INSTRUMENT FOR PRIVATE INVESTORS}

\author{
Elena I. Ignatenko, Irina A. Alekseeva \\ Baikal State University, Irkutsk, the Russian Federation
}

\section{Article info}

Received

July 12, 2017

Accepted

February 28, 2018

Available online

March 30, 2018

\section{Keywords}

Eurobonds; Eurobond products; investments; stock market; private investors

\begin{abstract}
At the time being, private investors commonly set themselves an aim to place monetary funds in reliable instruments with profitability above the inflation rate. Based on the Russian secondary Eurobonds market analysis and the profitability comparison of Eurobonds and commercial bank deposits, the Eurobonds are proved as highly reliable, moderate liquid instrument with profitability above the interest rates of bank deposits. The authors clarify the matter of Eurobonds, define the key characteristics and special aspects of Eurobonds as an investment instrument; they also give information on the circle of participants and market infrastructure of this financial instrument. The authors scrutinize Eurobond products offered to the investors by the Russian investment companies and banks; define the operating standards of the new Eurobond-based financial product intended for private investors.
\end{abstract}

В период стремительного развития мировых фринансовых рынков инвесторы рассматривают рынок ценных бумаг как сфреру для размещения накопленных денежных средств. В развитых и развивающихся странах одним из наиболее популярных и масштабных сегментов рынка ценных бумаг является рынок еврооблигаций, который представлен первичным и вторичным рынком, а также рынком производных фринансовых инструментов. Данный вид бумаг позволяет част- ным инвесторам сохранить и преумножить денежные средства в период нестабильности на мировых фринансовых рынках и низких ставок по банковским вкладам.

В России еврооблигации стали выпускаться в 1996 г. Но до сих пор основным направлением размещения денежных средств является банковская система. Однако с 2015 г. период наметившейся тенденции к снижению процентных ставок в экономике - частные инвесторы начали обращать свое внимание 
на еврооблигации и другие альтернативные банковскому депозиту инструменты.

Под еврооблигациями (eurobonds) обычно понимают облигации, размещаемые эмитентом с помощью международного синдиката андеррайтеров среди зарубежных инвесторов в валюте, как правило иностранной как для эмитента, так и для зарубежного инвестора, преимущественно на долгий срок. Еврооблигации относятся к евробумагам, наряду с евронотами, евровекселями и глобальными облигациями. Сейчас на долю еврооблигаций приходится более 75 \% всех выпусков евробумаг [1, с. 213].

Еврооблигации характеризуются следующими чертами:

- синдикат андеррайтеров, через которых размещаются еврооблигации, состоит из нескольких инвестиционных банков, из которых по меньшей мере два участника зарегистрированы в разных государствах;

- могут быть первоначально приобретены (в том числе по подписке) только при посредстве кредитной организации или другого финансового института;

- имеют значительные объемы выпуска;

- размещаются одновременно в нескольких странах, кроме страны регистрации эмитента.

Экономическая сущность еврооблигаций, как и облигаций в целом, заключается в том, что этот вид ценных бумаг выражает отношение займа между инвестором и эмитентом. По договору займа покупатель еврооблигации выступает кредитором эмитента, получая от него проценты в определенные заранее сроки, а по истечении срока договора - ее номинальную стоимость [1, с. $213 ; 2$, с. 154$]$.

Еврооблигациям присущи черты, которые во многом определили преимущества их рынка по сравнению с национальными рынками облигаций и другими направлениями инвестирования:

- являются наиболее надежными фринансовыми инструментами;

- отличаются высокой ликвидностью;

- предоставляют инвесторам доступ к значительно большему числу потенциальных эмитентов различного профиля, чем на национальных рынках;

- еврозаймы носят чисто финансовый характер, т. е. не связывают заемщика целевым использованием полученных средств;

- широкое разнообразие видов евробумаг позволяют инвестору выбрать наиболее приемлемые с точки зрения риска и доходности инструменты инвестирования;
- предоставляют возможность применять различные схемы оптимизации налогообложения [3, с. 224-227; 4, с. 120-121].

Однако еврооблигациям, как всякому финансовому инструменту, присущи риски, с которыми может столкнуться инвестор при их приобретении:

1. Процентный риск - риск, связанный с изменением процентной ставки. Цена типичной облигации двигается в направлении, противоположном движению процентных ставок. Рост процентных ставок обусловливает падение цены облигации, при падении процентных ставок цена на облигацию растет. Если владелец будет вынужден продать еврооблигацию раньше даты ее погашения, рост процентных ставок приведет к фиксации убытка [5, с. 323].

2. Риск реинвестиции. Инвестор рискует реинвестировать промежуточный денежный поток по более низким процентным ставкам. Доход, приносимый реинвестициями, зависит от преобладающего на рынке в момент реинвестирования уровня процентных ставок. Риск процентной ставки и риск реинвестиции способны сбалансировать друг друга [6, с. 24].

3. Кредитный риск - риск невыполнения эмитентом взятых на себя при выпуске облигаций обязательств по своевременной выплате процента и полному возвращению долга. Данная форма кредитного риска получила название «риск дефолта» [7, с. 62].

4. Риск инфляции. Данный риск значим для всех еврооблигаций, кроме облигаций с плавающей ставкой, привязанной к величине инфляции.

5. Риск ликвидности. Этот вид риска зависит от того, насколько легко инвестору продать облигацию. Основная мера измерения ликвидности - ширина котируемого дилером спрэда. При этом в евробондах эмитентов с высоким кредитным качеством и значительным объемом сделок данный риск минимален [8, с. 130].

6. Риск волатильности - риск негативного воздействия изменения процентных ставок на цену облигации. Риск может быть реализован в периоды крупных экономических кризисов, в особенности когда наиболее уязвимой частью экономики является банковская система [6, c. 24].

На рынке еврооблигаций существуют следующие основные категории участников: эмитенты, инвесторы и организации, составляющие его инфраструктуру - расчетно-депозитарные институты и посредники.

Всю совокупность эмитентов еврооблигаций можно разделить на две большие группы 
в зависимости от типа заемщика: суверенные заемщики и международные организации; банки, иные кредитные организации, национальные и транснациональные корпорации $[9$, с. 107].

Законодательство большинства стран не требует обязательной регистрации эмиссии и раскрытия информации для выпусков еврооблигаций. Тем не менее во многих государствах действует законодательство о ценных бумагах или налогообложении, те или иные нормы которого могут затрагивать эмиссию и обращение еврооблигаций [10, с. 154].

Среди другой категории участников рынка еврооблигаций - инвесторов - выделяются две группы - институциональные и розничные инвесторы. Большинство инвесторов на рынке еврооблигаций являются институциональными инвесторами. В роли розничных инвесторов в мировой практике на рынке еврооблигаций выступают, как правило, физические лица, желающие диверсифицировать свои сбережения или увеличить процентный доход путем приобретения ценных бумаг, номинированных в различных валютах.

Также на рынке еврооблигаций, как и на любом фондовом рынке, большое значение имеют депозитарии, клиринговые организации, информационные службы, посредники, которые составляют инфраструктуру рынка еврооблигаций [2, с. 107]. Они обеспечивают надежность рынка еврооблигаций, его стабильность и выполнение обязательств посредников и эмитентов перед кредиторами.

В качестве посредников на рынке еврооблигаций выступают крупнейшие инвестиционные банки и инвестиционные компании (например, брокеры и (или) дилеры), которые принимают участие в размещении бумаг [11, c. 263]. К посредникам также относятся рейтинговые организации. Наличие кредитного рейтинга в мировой практике в настоящее время является обязательным условием для выхода коммерческой организации или даже национального государства на рынок долговых обязательств.

С каждым годом объем мирового рынка еврооблигаций увеличивается, и сегодня, по данным информационного агентства Bloomberg, он занимает две трети всего долгового рынка'. Если в 2007 г. на вторичном рынке обращалось еврооблигаций на 11520 млрд дол., то на конец 2016 г. их объем вырос практически в два раза - до 21623 трлн дол. (рис. 1).

Столь существенный объем долгового еврооблигационного рынка позволяет инвесторам отлично диверсифицировать риски при инвестировании, а инвестиционным компаниям дает возможность формировать большое количество продуктов, в том числе производных, на основе еврооблигаций.

Принято считать, что еврооблигации, благодаря высокому уровню надежности и чуть более высоким процентным ставкам, являются для частных инвесторов хорошей альтернативой банковским вкладам. Чтобы убедиться в обоснованности такого утверждения, было проведено сравнение по пяти крупным российским банкам доходности еврооблигаций и депозитов в рублях и валюте на срок один год с возможностью снятия и пополнения (табл. 1).

'Bloomberg terminal. URL: https://www.bloomberg. com/terminal.

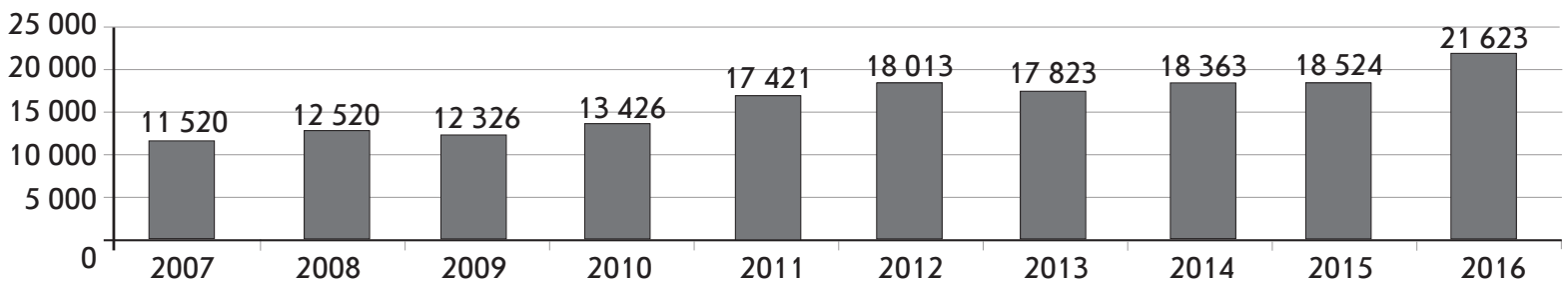

Рис. 1. Объем вторичного рынка еврооблигаций в мире в 2007-2016 гг., млрд дол.

Составлено по данным: Markets Stocks. URL: https://www.bloomberg.com/markets/stocks

Таблица 1

Сравнение доходности еврооблигаций и банковских вкладов

\begin{tabular}{|c|c|c|c|c|c|c|}
\hline \multirow[t]{2}{*}{ Банк } & $\begin{array}{c}\text { Доходность } \\
\text { еврооблигаций } \\
\text { к гашению с учетом } \\
\text { НДФЛ, дол. } \\
\end{array}$ & $\begin{array}{c}\text { Ставка } \\
\text { по вкладу }\end{array}$ & \multirow[t]{2}{*}{$\begin{array}{c}\text { Разница } \\
\text { ставок, } \\
\text { процентных } \\
\text { пунктов }\end{array}$} & $\begin{array}{c}\text { Доходность } \\
\text { еврооблигаций } \\
\text { к гашению } \\
\text { с учетом НДФЛ, р. }\end{array}$ & $\begin{array}{c}\text { Ставка } \\
\text { по вкладу } \\
\end{array}$ & \multirow[t]{2}{*}{$\begin{array}{c}\text { Разница } \\
\text { ставок, } \\
\text { процентных } \\
\text { пунктов }\end{array}$} \\
\hline & $\%$ & $\%$ & & $\%$ & $\%$ & \\
\hline ПАО «Промсвязьбанк» & 5,87 & 1,65 & 4,22 & 5,00 & 5 & 0 \\
\hline ПАО «Сбербанк» & 4,56 & 1 & 3,56 & 3,26 & 4,2 & $-0,94$ \\
\hline
\end{tabular}


Окончание табл. 1

\begin{tabular}{|c|c|c|c|c|c|c|}
\hline \multirow[t]{2}{*}{ Банк } & $\begin{array}{c}\text { Доходность } \\
\text { еврооблигаций } \\
\text { к гашению с учетом } \\
\text { НДФЛ, дол. } \\
\end{array}$ & $\begin{array}{c}\text { Ставка } \\
\text { по вкладу }\end{array}$ & \multirow[t]{2}{*}{$\begin{array}{c}\text { Разница } \\
\text { ставок, } \\
\text { процентных } \\
\text { пунктов }\end{array}$} & $\begin{array}{c}\text { Доходность } \\
\text { еврооблигаций } \\
\text { к гашению } \\
\text { с учетом НДФЛ, р. }\end{array}$ & $\begin{array}{c}\text { Ставка } \\
\text { по вкладу }\end{array}$ & \multirow[t]{2}{*}{$\begin{array}{c}\text { Разница } \\
\text { ставок, } \\
\text { процентных } \\
\text { пунктов }\end{array}$} \\
\hline & $\%$ & $\%$ & & $\%$ & $\%$ & \\
\hline ФК «Открытие» & 5,41 & 2,1 & 3,31 & 6,42 & 6,9 & $-0,48$ \\
\hline АО «Альфра-Банк» & 5,01 & 1,8 & 3,21 & 5,00 & 6,3 & $-1,30$ \\
\hline ПАО «Газпромбанк» & 3,39 & 1,45 & 1,94 & 5,87 & 5,5 & 0,37 \\
\hline
\end{tabular}

“ Составлена по данным: Bloomberg terminal. URL: https: / / www.bloomberg.com.

Доходность валютных еврооблигаций представленных банков варьирует от 3,39 до 5,87 \% годовых и превышает доходность долларовых вкладов, которая составляет от 1,0 до 2,1 \% годовых, на 1,94-4,22 процентного пункта. По рублевым еврооблигациям доходность выше ставки банковского вклада наблюдается только у одного банка - ПАО «Газпромбанк».

Таким образом, еврооблигации нельзя считать инструментом, доходность которого всегда выше доходности банковского вклада. В первую очередь прямая покупка еврооблигаций, т. е. без использования производных финансовых инструментов, интересна для инвесторов, которые размещают долларовые активы. Покупка рублевых еврооблигаций российских банков дает инвестору доходность к гашению ниже, чем по вкладам в данных банках.

Российские брокеры и банки предлагают инвесторам не только прямые вложения в еврооблигации, но и различные продукты и услуги на их основе. Чтобы рассмотреть возможности, которые предоставляют частным инвесторам российские инвестиционные компании и банки на рынке еврооблигаций, были выбраны фринансовые институты, на долю которых приходится более 75 \% рынка инвестиционных услуг [6, с. 23]. В выборку вошли ПАО «ВТБ24» и четыре компании: ЗАО «Сбербанк Капитал», ООО «Компания БКС», ОАО «Брокерский дом «Открытие», ООО «УК «Альфа Капитал». Все они предлагают 47 различных вариантов размещения денежных средств в еврооблигации (табл. 2). На текущий момент инвестор может разместить денежные средства в еврооблигации, включая их прямую покупку, по шести направлениям: доверительное управление, паевые инвестиционные фонды, консультационное брокерское обслуживание, биржевые и инвестиционные ноты, а также структурные продукты.

Максимальное количество предложений осуществляется в формате доверительного управления - его используют все профессиональные участники. Преобладание данного формата обусловлено тем, что доверительное управление как услуга оказывается на российском рынке ценных бумаг давно (с 1996 г.) и является более известной среди инвесторов и простой для понимания.

Количество инвестиционных продуктов с использованием еврооблигаций, шт. '

\begin{tabular}{|c|c|c|c|c|c|c|c|}
\hline Компания & $\begin{array}{c}\text { Консультацион- } \\
\text { ное брокерское } \\
\text { обслуживание }\end{array}$ & $\begin{array}{c}\text { Довери- } \\
\text { тельное } \\
\text { управление }\end{array}$ & $\begin{array}{c}\text { Паевой инвести- } \\
\text { ционный фронд }\end{array}$ & $\begin{array}{c}\text { Биржевые } \\
\text { ноты }\end{array}$ & $\begin{array}{c}\text { Инвестицион- } \\
\text { ные ноты }\end{array}$ & $\mid \begin{array}{c}\text { Структурные } \\
\text { продукты }\end{array}$ & Итого \\
\hline $\begin{array}{l}\text { ООО } \\
\text { «Компания } \\
\text { БКС» }\end{array}$ & 2 & 9 & 2 & 4 & 6 & 4 & 27 \\
\hline $\begin{array}{l}\text { ООО } \\
\text { «Сбербанк } \\
\text { Капитал» }\end{array}$ & 1 & 3 & 1 & 2 & - & - & 7 \\
\hline $\begin{array}{l}\text { ООО «Аль- } \\
\text { фа Капитал» }\end{array}$ & 1 & 3 & 2 & - & - & - & 6 \\
\hline $\begin{array}{l}\text { ФК «Откры- } \\
\text { тие» }\end{array}$ & 1 & 2 & 1 & - & - & - & 4 \\
\hline $\begin{array}{l}\text { ПАО } \\
\text { «ВТБ24» }\end{array}$ & 1 & 1 & 1 & - & - & - & 3 \\
\hline Всего & 6 & 18 & 7 & 6 & 6 & 4 & 47 \\
\hline
\end{tabular}

" Составлена по данным: Markets Stocks. URL: https://www.bloomberg.com/markets/stocks ; Sector Performance.

URL: https://www.bloomberg.com/markets. 
Лидер по количеству стратегий доверительного управления - ООО «Компания БКС». При этом для инвестиционных компаний проще разработать стратегии доверительного управления, нежели создать структурные продукты либо инвестиционные ноты.

Вторым по популярности инвестиционным продуктом является формат паевого инвестиционного фонда (ПИФ). Как правило, каждая управляющая компании имеет ПИФ, в состав имущества которого входят еврооблигации.

На текущий момент паевые инвестиционные фонды еврооблигаций представленных компаний объединяют под управлением имущество стоимостью 6,657 млрд р. ${ }^{2}$ Все фоонды были сформированы более десяти лет назад. Среднегодовая доходность фондов за прошедшие три года $-16,34$ \% годовых в рублях ${ }^{3}$.

Третье место среди инвестиционных продуктов анализируемых компаний делят консультационное брокерское обслуживание, биржевые ноты и инвестиционные ноты.

Консультационное брокерское обслуживание - услуга, оказываемая персональным брокером при формировании портфеля из еврооблигаций. Она предоставляется клиентам с активами, как правило, более 6,5 млн р. и относится к услугам премиального сервиса. Требуемая сумма активов связана с размером минимального лота покупки еврооблигаций - 200 тыс. дол.: персональные брокеры не рекомендуют покупать лоты меньшей стоимости из-за возможного отсутствия ликвидности бумаг в будущем.

Биржевые и инвестиционные ноты, а также структурные продукты предлагают своим клиентам мало компаний. Например,

${ }^{2}$ Рэнкинг ПИФ по СЧA. URL: http://www.nlu.ru/ pifs-scha.htm.

${ }^{3}$ Рэнкинг ПИФ по доходности. URL: http://www. nlu.ru/pif-doxod-renking.htm. инвестиционные ноты и структурные продукты на данный момент предлагает только ООО «Компания БКС», в то время как за рубежом они относятся к наиболее популярным продуктам среди частных инвесторов при размещении денег в еврооблигации.

Начиная с 2015 г. инвестиционные компании и банки, имеющие лицензии на осуществление брокерской деятельности и деятельности по управлению ценными бумагами, предлагают частным инвесторам услуги на основе средств, размещенных на индивидуальных инвестиционных счетах (ИИС). Такой счет открывается и ведется брокером или управляющим на основании отдельного договора на брокерское обслуживание или договора доверительного управления ценными бумагами, которые предусматривают открытие и ведение ИИС 4 .

Налоговый кодекс РФ предусматривает, что инвестор, использующий ИИС, может рассчитывать на гарантированный возврат $13 \%$ от суммы взноса на ИИС в виде налогового вычета либо на освобождение от уплаты НДФЛ с прибыли, полученной по счету. Для получения налоговых льгот счет должен просуществовать три года, максимальная ежегодная сумма взноса на ИИС ограничена 400 тыс. р. ${ }^{5}$ За два года российскими компаниями и банками было открыто более 217 тыс. счетов [6, с. 23].

Инвестиционные продукты на основе еврооблигаций как объект инвестиций средств, находящихся на ИИС, предлагают своим клиентам все анализируемые компании. Наибольшее количество таких продуктов (11) разработано ООО «Компания БКС » (табл. 3).

${ }^{4}$ О рынке ценных бумаг : федер. закон от 22 апр. 1996 г. № 39-Ф3 (ред. от 31 дек. 2017 г.). Статья 10.2-1 // СПС «КонсультантПлюс».

${ }^{5}$ Налоговый кодекс Российской Федерации. Часть вторая : федер. закон от 5 авг. 2000 г. № 117-Ф3 (ред. от 7 марта 2018 г.). Статья 219.1 / / Там же.

Количество продуктов с использованием еврооблигаций для ИИС, шт.

Таблица 3

\begin{tabular}{|l|r|r|r|r|r|r|r|}
\hline \multicolumn{1}{|c|}{ Компания } & $\begin{array}{c}\text { Консультацион- } \\
\text { ное брокерское } \\
\text { обслуживание }\end{array}$ & $\begin{array}{c}\text { Довери- } \\
\text { тельное } \\
\text { управление }\end{array}$ & $\begin{array}{c}\text { Паевой } \\
\text { инестицион- } \\
\text { ный фонд }\end{array}$ & $\begin{array}{c}\text { Биржевые } \\
\text { ноты }\end{array}$ & $\begin{array}{l}\text { Инвести- } \\
\text { ционные } \\
\text { ноты }\end{array}$ & $\begin{array}{c}\text { Структурные } \\
\text { продукты }\end{array}$ & Итого \\
\hline ООО «Компания БКС» & - & 2 & 2 & 3 & 1 & - & 2 \\
\hline $\begin{array}{l}\text { ООО «Сбербанк } \\
\text { Капитал» }\end{array}$ & - & 1 & 1 & - & - & - & 1 \\
\hline ООО «Альра Капитал» & - & - & 1 & - & - & - & 1 \\
\hline ФК «Открытие» & - & - & 1 & - & - & - & 1 \\
\hline ПАО «ВТБ24» & - & - & 1 & - & - & 3 & 16 \\
\hline Всего & - & 3 & 6 & 3 & 1 & \\
\hline
\end{tabular}

* Составлена по данным: Sector Performance. URL: https://www.bloomberg.com/markets. 
Основное количество инвестиционных продуктов связано с паевыми инвестиционными фондами. Обусловлено это тем, что максимальный взнос на ИИС ограничен 400 тыс. р. в год, а инвестиционный пай ПИФа - наиболее доступный с точки зрения стоимости приобретения фринансовый инструмент.

Повышенный интерес инвесторов к еврооблигациям обусловливает достаточно широкий спектр еврооблигационных продуктов на российском фондовом рынке. Рассмотрим параметры данных продуктов с тем, чтобы ответить на вопрос, отвечают ли предложенные продукты требованиям частных инвесторов.

Первый параметр - это срок, на который инвестор может разместить свои денежные средства (табл. 4).

Наибольшая часть инструментов на основе еврооблигаций представлена продуктами, которые не привязаны к конкретному сроку, имеют только рекомендованный срок размещения активов в данном продукте либо срок инвестирования обозначен как «не менее чем на один год".

Вместе с тем с точки зрения максимально эфрфективного размещения денежных средств в еврооблигации на текущий момент аналитики рекомендуют рассматривать продукты с длительным сроком размещения. Объясняется это тем, что в период снижения ставок по банковским вкладам такие продукты позволяют инвесторам зафиксировать высокую процентную ставку на длительный промежуток времени.

Что касается другого параметра - валюты продукта, то валютная диверсификация продуктов на основе еврооблигаций на российском рынке достаточно широка. Все анализируемые компании дают возможность клиентам разместить активы в рублях и долларах; есть предложения по продуктам в евро и фунтах стерлингов; ООО «Компания БКС» предоставляет возможность разместить денежные средства в еврооблигации, номинированные в юанях и швейцарских франках (табл. 5).

Немаловажным параметром при принятии решения об инвестировании в еврооблигации для инвесторов является минимальная сумма для инвестиций. На текущий момент инвестиционные компании стараются сделать рынок более доступным, поэтому появились продукты с минимальным порогом для покупки - менее 200 тыс. дол. На рис. 2 представлен график количества продуктовых предложений, ранжированный по минимально необходимой сумме для покупки еврооблигационных продуктов (в рублях и в валютном эквиваленте).

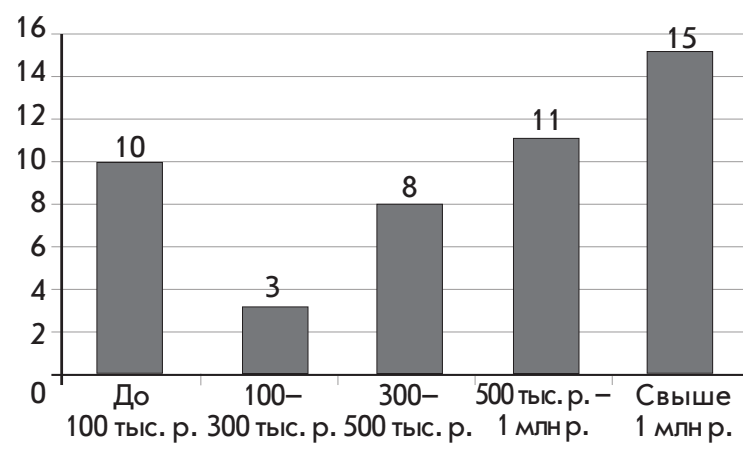

Рис. 2. Количество продуктовых предложений, сгруппированных по минимальной сумме покупки

Составлено по данным: Sector Performance. URL: https://www.bloomberg.com/markets

Срок инвестиционных продуктов на основе еврооблигаций

Таблица 4

\begin{tabular}{|l|r|r|r|r|r|r|}
\hline \multicolumn{1}{|c|}{ Компания } & Один год & Два года & Три года & Четыре года & Пять лет & Нет привязки к сроку \\
\hline ООО «Компания БКС» & + & + & + & + & + & + \\
\hline ООО «Сбербанк Капитал» & + & - & - & + & - & + \\
\hline ООО «Альфа Капитал» & + & - & - & - & - & - \\
\hline ФК «Открытие» & + & - & - & - & - & + \\
\hline ПАО «ВТБ24» & - & - & - & - & - & + \\
\hline
\end{tabular}

* Составлена по данным: Sector Performance. URL: https://www.bloomberg.com/markets.

Таблица 5

Валюта инвестиционных продуктов на основе еврооблигаций

\begin{tabular}{|c|c|c|c|c|}
\hline ООО «Компания БКС» & ФК «Открытие» & $\begin{array}{c}\text { ООО «Сбербанк } \\
\text { Капитал» }\end{array}$ & ПАО «ВТБ24» & $\begin{array}{c}\text { ООО «Альфра } \\
\text { Капитал» }\end{array}$ \\
\hline $\begin{array}{l}\text { Рубль, доллар, евро, юань, } \\
\text { швейцарский франк, фунт } \\
\text { стерлингов }\end{array}$ & $\begin{array}{l}\text { Рубль, доллар, евро, } \\
\text { по запросу фунт } \\
\text { стерлингов }\end{array}$ & Рубль, доллар, евро & Рубль, доллар & Рубль, доллар \\
\hline
\end{tabular}

* Составлена по данным: Sector Performance. URL: https://www.bloomberg.com/markets. 
Меньше всего предложений продуктов стоимостью от 100 тыс. р. до 300 тыс. р. В данный сегмент входят структурные продукты ООО «Компания БКС» формата «Облигационный FTD».

На текущий момент наибольшее количество продуктов, основанных на евробондах, доступно клиентам, которые обладают минимальным объемом активов от 1 млн р. и выше. В данный ценовой сегмент вошли такие продукты, как консультационное брокерское обслуживание, биржевые ноты ООО «Сбербанк Капитал» и инвестиционные ноты ООО «Компания БКС».

Группа продуктов с минимально необходимой суммой клиентских активов от 500 тыс. до 1 млн р. представлена доверительным управлением ООО «Компания БКС», ООО «Сбербанк Капитал», ФК «Открытие», а также ООО «Альфра Капитал».

Еврооблигационные продукты, для покупки которых инвестору требуется объем активов менее 100 тыс. р., представлены паевыми инвестиционными фондами еврооблигаций, а также биржевыми нотами - их предлагает ООО «Компания БКС».

Как показывает практика, для частного инвестора основным критерием выбора продукта для инвестиций являются ставки купонного дохода. На рис. 3 представлены по анализируемым инвестиционным компаниям процентные ставки валютных инвестиционных продуктов, основанных на еврооблигациях. Они находятся в диапазоне от 2,5 \% годовых до 15,0 \% годовых в валюте.

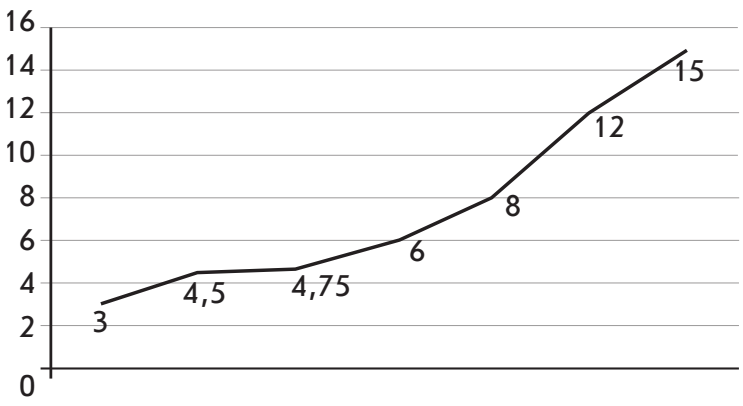

Рис. 3. Купонные процентные ставки еврооблигационных продуктов

в иностранной валюте (на 13 мая 2017 г.)

Составлено по данным: Bloomberg terminal. URL: https://www.bloomberg.com

Градация процентных ставок зависит от риск-профиля клиента. Он определяется на основе допустимого риска - риска, который способен нести клиент. По данным ООО «Компания БКС», большая часть клиентов имеет умеренно консервативный либо рациональный профиль, при котором с вероятностью 95 \% максимальная потеря капитала не превысит 5 и 10 \% соответственно. Наиболее распространенными продуктами для таких клиентов являются еврооблигационные продукты со ставкой купона до 7,5\% годовых в валюте.

Что касается инвестиционных продуктов, номинированных в рублях, то процентные ставки по ним находятся в диапазоне от 8 до $18 \%$ годовых (рис. 4).

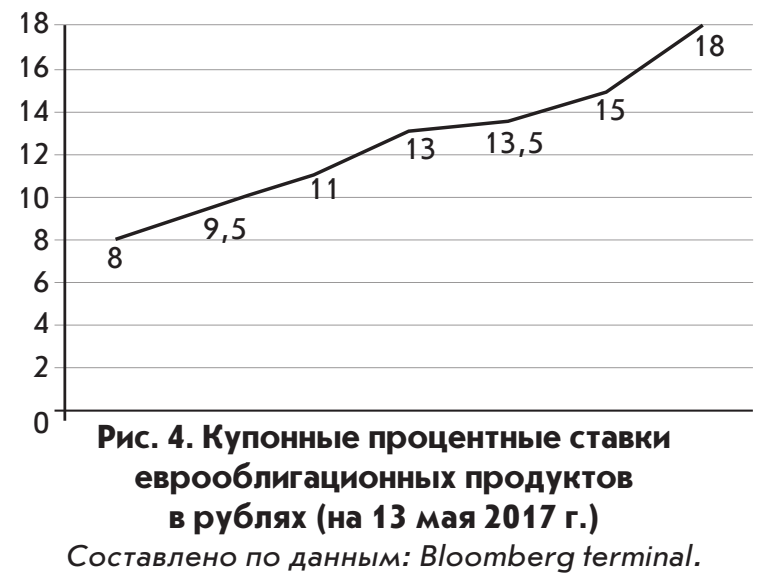
URL: https://www.bloomberg.com

Минимальную процентную ставку инвестор может зафиксировать при покупке рублевых евробондов российских банков. Максимальный доход в размере 18 \% годовых инвестор может заработать, если разместит денежные средства в ФК «Открытие», выбрав стратегию доверительного управления. Данная стратегия основана на еврооблигациях иностранных эмитентов, которая допускает использование маржинального плеча.

Таким образом, как показал анализ, продукты российских инвестиционных компаний, основанные на еврооблигациях, предлагаемые частным инвесторам, обладают следующими характерными чертами.

Во-первых, бо́льшая часть инвестиционных предложений сформирована в фрормате доверительного управления либо паевых инвестиционных фондов, поэтому на рынке преобладают инструменты с ожидаемыми, а не фиксированными процентными ставками. Причем данные формы еврооблигационных продуктов являются для фризических лиц более понятными, нежели структурные продукты или инвестиционные ноты.

Во-вторых, компании, создавая продукты, учитывают спрос инвесторов на среднесрочные инструменты либо на инструменты, не требующие определенного срока для инвестирования.

В-третьих, инвестору для получения доходности по еврооблигационным продук- 
там, превосходящей ставки по банковским вкладам, при выбранном уровне риска необходимо приобретать выпуски еврооблигаций не одного эмитента, а формировать диверсифицированный по эмитентам портфель.

В-четвертых, сейчас на рынке преобладают основанные на еврооблигациях продукты с минимальной суммой денежных средств для инвестиций - от 1 млн р., т. е. компании ориентированы на создание продуктов для клиентов премиум-сегмента.

Как можно заметить, на рынке отсутствует инвестиционный продукт со следующими параметрами:
- отсутствие фриксированного срока инструмента;

- наличие гарантированного купона;

- возможность инвестора получить доходность выше гарантированной доходности;

- невысокая минимальная сумма для покупки продукта;

- валюта номинирования - доллар США.

Это обусловливает необходимость разработки продукта с такими параметрами. Предложенный продукт отвечает инвестиционным запросам частных инвесторов, значит, может привлечь их на фондовый рынок, в чем заинтересовано не только профессиональное сообщество, но и государство.

\section{СПИСОК ИСПОЛЬЗОВАННОЙ ЛИТЕРАТУРЫ}

1. Фабоцци Ф. Д. Рынок облигаций: анализ и стратегии / Ф. Д. Фабоцци ; пер. с англ. А. Левинзон. - 2-е изд., испр. и доп. - М. : Альпина Бизнес Букс, 2007. - 950 с.

2. Рынок ценных бумаг : учеб. пособие / А. Ю. Архипов [и др.]. - Ростов н/Д. : Феникс, 2005. - 345 с.

3. Галанов В. А. Рынок ценных бумаг : учебник / В. А. Галанов. - М. : Инфра-М, 2007. - 379 с.

4. Селищев А. С. Рынок ценных бумаг : учебник / А. С. Селищев, Г. А. Маховикова. - 3-е изд., перераб. и доп. - М. : Юрайт, 2016. - 483 с.

5. Чувахина Л. Г. Еврооблигации и рынок евробумаг / Л. Г. Чувахина / / Вопросы современной науки и практики. - 2011. - № 2. - С. 322-326.

6. Сосновский Г. И. В России экономические решения принимаются с точки зрения политической воли [Электронный ресурс] / Г. И. Сосновский. - Режим доступа: https://www.om1.ru/bank/ news / 64982 .

7. Ковалева Н. А. Механизмы выпуска еврооблигаций: мировой опыт и российские особенности / Н. А. Ковалева / / Управление в кредитной организации. - 2013. - № 4. - С. 61-64.

8. Рынок ценных бумаг : учебник / под ред. Н. И. Берзона. - М. : Юрайт, 2011. - 531 с.

9. Лазин А. В. Организация выпуска еврооблигаций: мировой опыт и российская специфика / А. В. Лазин / / Рынок ценных бумаг. - 2004. - № 23 (278). - С. 106-110.

10. Выговский А. И. Еврооблигации как инструмент международного рынка капитала: особенности правового режима регулирования / А. И. Выговский // Современное право. - 2009. - № 11. C. $153-156$.

11. Рубцов Б. Б. Современные финансовые рынки : учеб. пособие / Б. Б. Рубцов. - М. : Альпина Бизнес Букс, 2007. - 926 с.

\section{REFERENCES}

1. Fabozzi F. J. Bond Markets, Analysis and Strategies. Upper Saddle River, Prentice-Hall International, Inc., 1996. 595 p. (Russ. ed.: Fabozzi F. J. Rynok obligatsii: analiz i strategii. $2^{\text {nd }}$ ed. Moscow, Al'pina Biznes Buks Publ., 2007. 950 p.).

2. Arkhipov A. Yu., Shikhirev V. V., Denisov G. M., Kravtsov S. A. (eds.). Rynok tsennykh bumag [Stock Market]. Rostov-on-don, Feniks Publ., 2005. 345 p.

3. Galanov V. A. Rynok tsennykh bumag [Stock Market]. Moscow, Infra-M Publ., 2007. 379 p.

4. Selishchev A. S., Makhovikova G. A. Rynok tsennykh bumag [Stock Market]. $3^{\text {rd }}$ ed. Moscow, Yurait Publ., 2016. 483 p.

5. Chuvakhina L. G. Eurobonds and the Eurocommercial Paper Market. Voprosy sovremennoi nauki i praktiki= Problems of Contemporary Science and Practice, 2011, no. 2, pp. 322-326. (In Russian).

6. Sosnovsky G. I. V Rossii ekonomicheskie resheniya prinimayutsya s tochki zreniya politicheskoi voli [Economic Solutions in Russia Are Made According to Political Will]. Available at: https://www.om1 .ru/bank/news/64982. (In Russian).

7. Kovaleva N. A. Euroissue mechanisms: World Experience and Russian Peculiarities. Upravlenie $v$ kreditnoi organizatsii = Management in the Financial Institutiont, 2013, no. 4, pp. 61-64. (In Russian).

8. Berzon N. I. (ed.). Rynok tsennykh bumag [Stock Market]. Moscow, Yurait Publ., 2011. 531 p.

9. Lazin A. V. Euroissuing Organization: World Experience and Russian Peculiarities. Rynok tsennykh bumag= Stock Market, 2004, no. 23 (278), pp. 106-110. (In Russian).

10. Vygovsky A. I. Eurobonds as an International Capital Market Instrument: Peculiarities of the Legal Regulation. Sovremennoe pravo = Modern law, 2009, no. 11, pp. 153-156. (In Russian).

11. Rubtsov B. B. Sovremennye finansovye rynki [Modern Financial Markets]. Moscow, Al'pina Biznes Buks Publ., 2007. 926 p. 


\section{Информация об авторах}

Игнатенко Елена Игоревна - магистр, кафедра банковского дела и ценных бумаг, Байкальский государственный университет, 664003, г. Иркутск, ул. Ленина, 11, e-mail: ignatenko304@gmail.com.

Алексеева Ирина Анатольевна - кандидат экономических наук, доцент, кафедра банковского дела и ценных бумаг, Байкальский государственный университет, 664003, г. Иркутск, ул. Ленина, 11, e-mail: ialekseeva28_02@mail.ru.

\section{Для цитирования}

Игнатенко Е. И. Еврооблигации как инвестиционный инструмент для частных инвесторов / Е. И. Игнатенко, И.А.Алексеева // Известия Байкальского государственного университета. - 2018. - Т. 28, № 1. - C. 114-122. - DOI: $10.17150 / 2500-$ 2759.2018.28(1).114-122.

\section{Authors}

Elena I. Ignatenko - Master Student, Department of Banking and Securities, Baikal State University, 11 Lenin St., 664003, Irkutsk, the Russian Federation, e-mail: ignatenko304@gmail.com.

Irina A. Alekseeva - PhD in Economics, Associate Professor, Department of Banking and Securities, Baikal State University, 11 Lenin St., 664003, Irkutsk, the Russian Federation, e-mail: ialekseeva28_02@mail.ru.

\section{For citation}

Ignatenko E. I., Alekseeva I. A. Eurobonds as an Investment Instrument for Private Investors. Izvestiya Baykal' skogo gosudarstvennogo universiteta $=$ Bulletin of Baikal State University, 2018, vol. 28, no. 1, pp. 114122. DOI: $10.17150 / 2500-2759.2018 .28(1) .114-122$. (In Russian). 